\title{
Evaluation of Plasmatic Levels of Negative and Positive Acute Hepatic Phase Proteins in Patients who Underwent Major Surgery
}

\author{
LAURA NICOLESCU1,2\#, BOGDAN TOTOLICI ${ }^{1,2}$, OVIDIU BEDREAG ${ }^{3,4}$, CRISTIAN NICOLESCU2*\#, ALIN MIHU ${ }^{1,2 *}$ \\ 'West University Vasile Goldis, 94 Revolutiei Blvd., 310130, Arad, Romania \\ ${ }^{2}$ Clinical County Emergency Hospital, 2-4 A Karoly,Str., 310037, Arad, Romania \\ ${ }^{3}$ University of Medicine Victor Babes, 2 Eftimie Murgu Sq., 300041,Timisoara, Romania \\ ${ }^{4}$ Clinical County Emergency Hospital, 156 L.Rebreanu Blvd., 300723, Timisoara, Romania
}

\begin{abstract}
The acute hepatic phase response is defined as a reaction that includes hepatic synthesis of proteins, consisting in the increase of some proteins called positive acute phase proteins and the simultaneous decrease of others called negative acute phase proteins. This study describes this hepatic reaction, based on a series of consecutive determinations, at three different time intervals (right before a major surgery event, 24 and 48 hours after the intervention), of the plasmatic levels of transferrin, albumin, fibrinogen and $C$ reactive protein (CRP). Subsequently, the data was analyzed using Jamovi 2019 , version 0.9 . The inferential statistics consisted in calculating an ANOVA test that compared the values at 24 hours and 48 hours versus the values right before the major surgery. The results were validated by calculating the $p$ value $(p<0.05)$ as well as conducting correlation tests by determining the Pearson coefficient which shows the values of CRP, fibrinogen, transferrin and albumin are independent of each other and do not interact. The multiple ANOVA comparative test reveals the lack of interaction between the values of determined proteins, regardless of the moment of determination.
\end{abstract}

Key words: albumin, transferrin, C reactive protein, fibrinogen, acute phase protein,

The acute hepatic phase response occurs as a result of tissue trauma, infection or a systemic inflammation. It is triggered in the liver by interleukin 1(IL1) and interleukin 6(IL6). This reaction has been proved to be the main mechanism of decreasing the plasmatic level of albumin in patients undergoing major surgery $[1,48]$.These interleukins are particularly produced by the macrophages in the damaged tissue $[2,3]$. This acute phase reaction belongs to a systemic response, coordinated by interleukins [4].

An acute phase protein is considered a protein which changes its plasmatic concentration with at least $25 \%$ of its initial value [24]. The role of positive acute phase proteins is mainly to stimulate the innate immune system by activating the complement system as well as antibody opsonization [51].

These positive acute phase proteins are divided into two groups. The first one is represented by the serum amyloid, $C$ reactive protein(CRP), Complement 3 , Complement 4 and alpha glycoproteins. Their synthesis in the liver is initiated by the IL1-like cytokines, which comprises different types of IL1-cytokines and tumor necrosis factors $[25,26]$. The second group is represented by fibrinogen, alpha 1 antichymotripsyn, alpha 1 trypsin, and alpha 2 macroglobulin. These proteins are also synthesized by the liver in response to IL6 as well as IL6-like cytokines (leukemia inhibitor factor, oncostatin, M,cardiotrophin-1) [27-29].

The action mechanism of both interleukins is similar. It consists in binding to a specific receptor. The receptor for IL1 has a molecular mass of $80 \mathrm{kda}$ [5-7] and the receptor for IL6 has a molecular mass of $68 \mathrm{kda}$ [9-11]. Structurally, both receptors belong to the immunoglobulin superfamily. Their concentration, low in normal conditions, increases in the liver as a response to systemic inflammation [8].

The genetic transcription factor plays an essential role in the synthesis of these proteins and is produced by two separate mechanisms [18-20]. First, in case of IL1, the enzymatic system is stimulated by the synthesis of ceramide proteins which activate protein kinase $[16,17]$. Second, in case of IL6, the enzymatic system is stimulated by the phosphorylation of tyrosine [12-15].

This genetic transcription factor is represented by messenger Ribonucleic Acid (mRNA) and has a role in transporting the genetic information from the nucleus to ribosomes. Genetic information codes amino acid sequences into protein structures [21-23].Finally, protein synthesis takes place in this ribosomes by binding mRNA with transport Ribonucleic Acid (tRNA).

In order for these proteins to be synthesized in the ribosomes, an amino acid substrate and an energetic substrate need to exist beside the genetic transcription factor $[30,31]$.

Former authors indicate that acute positive phase proteins increase as the negative proteins decrease. These authors consider that the available amino acid substrate is limited in the setting of systemic inflammation, due to the catabolism of proteins[32].

Negative acute phase proteins are mainly represented by albumin(its main role being to determine the colloidosmotic pressure) and transferrin(a plasmatic globulin which has the role in transporting iron from the blood to its storages found in the liver, spleen and bone marrow) [49].

The latest study done on this topic is from 2005 where Gruys et.al. studied the acute phase reaction in animals [48]. To our knowledge, our studyis the first one on humans, which determines fibrinogen, CRP, albumin and transferrin and compares them statistically.

\section{Experimental part \\ Material and methods}

Sixty two patients were included in this study. Thirty patients were male and thirty two were female, the average age was 55, 3 years old( ranging from 39 years old to 91 
years old). Patients presenting associated hepatic or renal pathology that can lead to a decrease of albumin and transferrin levels in plasma, malnutrition and/or diarrheal disease were excluded from the study. Hemolyzed or lipemic serums were not investigated.

The determinations done for these patients were: total protein, alanine aminotransferase (ALT), aspartate aminotransferase (AST), total and direct bilirubin, CRP, fibrinogen, transferrin and albumin .

Determination of albuminemia was done using a dry chemistry method on Samsung LABGEO. The method is based on binding albumin with a pigment substance in an acidic environment. This binding produces a change in color from yellow to purple. This change is quantified using spectrophotometry. Normal values of serum albumin range between $3.5-5.0 \mathrm{~g} / \mathrm{dL}$. The reaction at the basis of determining the albuminemia level is:

$$
\begin{gathered}
\text { Albumin + Brooches purple (BCP) } \rightarrow \text { Ph. Acid BCP - } \\
\text { Albumin Complex } \\
\text { Total proteins were determined on Samsung LABGEO. }
\end{gathered}
$$
The method used was based of the reaction of these proteins with $\mathrm{Cu}^{+2}$ and measuring the resulting complex using spectrophotometry. Normal values of total proteins range between 6 - $8 \mathrm{~g} / \mathrm{dL}$.

Total protein $+\mathrm{Cu}^{+2} \rightarrow \mathrm{OH}$ - Protein-Cu complex

The determination of liver transaminase levels (ALT and AST) was based on the colorimetric method done on Samsung LABGEO. Bilirubin levels were measured using the enzyme oxidation method. The precision of the measurements were evaluated according to the standard guidelines issued by the Institution of Clinical Studies, USA. The precision was evaluated using BIO-RAD level 1-3 and the result showed that the variation coefficient was less than $5 \%$ in each determination.

To determine the plasmatic transferrin levels, the method was imunenephelometry, using BN ProSpec system by Siemens. The principle used by this method is based on forming complexes with specific antibodies. This complex diffuses a light beam which runs through the test. The intensity of the diffused light beam is proportional with the relevant protein concentrate in the test. The result is assessed by comparing it with a standard concentration. Normal transferrin levels in the plasma are between 2.00$3.60 \mathrm{~g} / \mathrm{L}$ in subjects older than 19 years.

To determine the fibrinogen level in the plasma, we used Diagnostica Stago STA fully automated Coagulation Analyzer by Artisan Technology Group. This analyzer determines the fibrinogen concentration in the plasma quantitatively using the Clauss clotting method. This testing method involves the measuring the rate of fibrinogen to fibrin conversion in a diluted sample under the influence of excess thrombin. Since under these conditions the fibrinogen content is rate limiting, the clotting time can be used as a measure of the concentration of the fibrinogen and in fact the clotting time is inversely proportional to the level of fibrinogen in the plasma. Normal values are between $150-400 \mathrm{mg} / \mathrm{dL}$.

CRP was determined quantitatively in vitro using Immunoturbidimetric assay on Roche/Hitachi Cobas c501 by Siemens. CRP in human plasma agglutinates with latex particles coated with monoclonal-CRP-antibodies. The aggregates are determined turbidimetrically. Normal values range between 0.00 and $0.50 \mathrm{mg} / \mathrm{dL}$.

This study was approved by the Ethical Committee of Arad Clinical County Hospital. Written consent was obtained from all participants.

The statistical part of this study is based on descriptive statistics and inferential statistics. The inferential statistics are comprised of ANOVA tests as well as correlation tests. In both situations we consider a statistically significant $p<0.05$. ( $p$ representing the error probability)

\section{Results and discussions}

Results are presented in the tables below, our results indicate that the variances and standard deviations are low in case of negative acute phase proteins and high in case of positive acute phase proteins.

\begin{tabular}{lrrrr}
\hline Descriptives & Al RIIMIN & FIB & CRP & TRANSFFRRIN \\
\hline $\mathrm{N}$ & 62 & 62 & 62 & 62 \\
Missing & 0 & 0 & 0 & 0 \\
Mean & 4.13 & 270 & 17.3 & 2.74 \\
Median & 4.10 & 260 & 12.0 & 2.70 \\
Standard deviation & 0.460 & 60.9 & 17.1 & 0.321 \\
Variance & 0.211 & 3715 & 293 & 0.103 \\
Minimum & 3.20 & 120 & 1.00 & 2.10 \\
Maximum & 4.80 & 440 & 85.0 & 3.40 \\
25th percentile & 3.80 & 230 & 6.11 & 2.50 \\
5Oth percentile & 4.10 & 260 & 12.0 & 2.70 \\
75th percentile & 4.47 & 298 & 24.8 & 2.98 \\
\hline
\end{tabular}

\begin{tabular}{|lrrrc|}
\hline Descriptives & ALB /24 & FIB /24 & CRP /24 & TRANSFERRIN /24 \\
\hline $\mathrm{N}$ & 62 & 62 & 62 & 62 \\
Missing & 0 & 0 & 0 & 0 \\
Mean & 3.24 & 444 & 71.9 & 1.96 \\
Median & 3.20 & 440 & 74.0 & 2.00 \\
Standard deviation & 0.262 & 105 & 41.1 & 0.263 \\
Variance & 0.0687 & 11085 & 1692 & 0.0690 \\
Minimum & 2.70 & 270 & 5 & 1.50 \\
Maximum & 3.60 & 870 & 160 & 2.40 \\
25th percentile & 3.02 & 364 & 35.0 & 1.72 \\
50th percentile & 3.20 & 440 & 74.0 & 2.00 \\
75th percentile & 3.40 & 498 & 90.0 & 2.20 \\
\hline
\end{tabular}




\begin{tabular}{|lrrrr|}
\hline Descriptives & \multicolumn{7}{c|}{} \\
\hline & ALB /48 & FIB /48 & CRP /48 & TRANSFERRIN /48 \\
\hline $\mathrm{N}$ & 62 & 62 & 62 & 62 \\
Missing & 126 & 126 & 126 & 126 \\
Mean & 2.99 & 572 & 146 & 1.60 \\
Median & 3.00 & 565 & 145 & 1.60 \\
Standard deviation & 0.275 & 143 & 65.4 & 0.229 \\
Variance & 0.0759 & 20518 & 4272 & 0.0526 \\
Minimum & 2.50 & 340 & 31 & 1.30 \\
Maximum & 3.50 & 980 & 350 & 2.10 \\
25th percentile & 2.73 & 450 & 95.3 & 1.40 \\
50th percentile & 3.00 & 565 & 145 & 1.60 \\
75th percentile & 3.20 & 678 & 180 & 1.80 \\
\hline
\end{tabular}

Table 4

DIFFERENCE IN FIBRINOGEN AT THREE DIFFERENT TIME INTERVALS: BEFORE THE MAJOR SURGERY, 24 AND 48 hours AFTER THE INTERVENTION AS WELL AS BETWEEN 24 and 48 hours

\begin{tabular}{|c|c|c|c|c|}
\hline \multicolumn{5}{|c|}{ Tukey Post-Hoc Test - FIB $0-24-48$} \\
\hline & & 1 & 2 & 3 \\
\hline \multirow[t]{2}{*}{1} & Mean difference & - & -174 & -302 \\
\hline & $\mathrm{p}$-value & - & $<.001$ & $<.001$ \\
\hline \multirow[t]{2}{*}{2} & Mean difference & & - & -127 \\
\hline & p-value & & - & $<.001$ \\
\hline \multirow[t]{2}{*}{3} & Mean difference & & & 一 \\
\hline & p-value & & & - \\
\hline
\end{tabular}

From the inferential statistics, our results demonstrate that ANOVA test is validated in case of all determined proteins.

Table 5

DIFFERENCE IN PLASMA ALBUMIN AT THREE DIFFERENT TIME INTERVALS: BEFORE THE MAJ OR SURGERY, 24 AND 48 HOURS AFTER INTERVENTION AS WELL AS BETWEEN 24 AND 48 hours

\begin{tabular}{|c|c|c|c|c|}
\hline \multicolumn{5}{|c|}{ Tukey Post-Hoc Test - ALB $0-24-48$} \\
\hline & & 1 & 2 & 3 \\
\hline \multirow[t]{2}{*}{1} & Mean difference & - & 0.887 & 1.140 \\
\hline & $\mathrm{p}$-value & - & $<.001$ & $<.001$ \\
\hline \multirow[t]{2}{*}{2} & Mean difference & & - & 0.253 \\
\hline & p-value & & - & $<.001$ \\
\hline \multirow[t]{2}{*}{3} & Mean difference & & & - \\
\hline & $\mathrm{p}$-value & & & - \\
\hline
\end{tabular}

Table 6

DIFFERENCE IN PLASMA TRANSFERRIN AT THREE DIFFERENT TIME INTERVALS: BEFORE THE MAJ OR SURGERY, 24 AND 48 hours AFTER THE INTERVENTION AS WELL AS BETWEEN 24 and 48 hours

\begin{tabular}{|c|c|c|c|c|}
\hline \multicolumn{5}{|c|}{ Tukey Post-Hoc Test - TRANSFERRIN $0-24-48$} \\
\hline & & 1 & 2 & 3 \\
\hline \multirow[t]{2}{*}{1} & Mean difference & - & 0.777 & 1.132 \\
\hline & p-value & - & $<.001$ & $<.001$ \\
\hline \multirow[t]{2}{*}{2} & Mean difference & & - & 0.355 \\
\hline & p-value & & - & $<.001$ \\
\hline \multirow[t]{2}{*}{3} & Mean difference & & & - \\
\hline & $\mathrm{p}$-value & & & - \\
\hline
\end{tabular}

Table 3

VALUES OF ALBUMIN, FIBRINOGEN, CRP AND TRANSFERRIN 48 hours AFTER THE MAJ OR SURGERY
Table 7

DIFFERENCE IN PLASMA CRP AT THREE DIFFERENT TIME INTERVALS: PRE-SURGICAL TRAUMA, 24 AND 48 hours AFTER THE INTERVENTION AS WELL AS BETWEEN 24 AND 48 hours

\begin{tabular}{|c|c|c|c|c|}
\hline \multicolumn{5}{|c|}{ Tukey Post-Hoc Test - CRP 0 -24 -48 } \\
\hline & & 1 & 2 & 3 \\
\hline \multirow[t]{2}{*}{1} & Mean difference & - & -54.6 & -129.2 \\
\hline & p-value & - & $<.001$ & $<.001$ \\
\hline \multirow[t]{2}{*}{2} & Mean difference & & - & -74.6 \\
\hline & p-value & & - & $<.001$ \\
\hline \multirow[t]{2}{*}{3} & Mean difference & & & - \\
\hline & $\mathrm{p}$-value & & & - \\
\hline
\end{tabular}

After obtaining these values ( $p<0.001)$, we proceeded in illustrating the graphics in order to compare the changes between albumin and transferrin and also, between fibrinogen and CRP.

We also conducted correlation tests between the values of albumin, transferrin, CRP and fibrinogen test results before the major surgery, 24 hours and 48 hours after the intervention.

We also evaluated the correlation between of albumin and total protein test results in order to show the tests performed above are accurate (Table 11).

Multiple comparison ANOVA tests were also performed (Table 12 and 13)

The descriptive statistics that the standard deviations and variations are low in case of negative acute phase proteins and different in case of positive acute phase proteins.

All the differences between the mean values of each protein (before the major surgery, at 24 and 48 hours after) were statistically significant $(p<0.001)$.

We observed the same trend change in case of albumin and transferrin but a different trend change in case of fibrinogen and CRP. This may be explained by the molecular structure of these proteins and the common amino acid substrate needed for synthesis [34]. Albumin and transferrin have a relatively similar composition.

Albumin has a molecular mass of $68 \mathrm{kda}$ and 585 amino acids in its structure, while transferrin has a molecular mass of $79 \mathrm{kda}$ and 670 amino acids in its structure [43, 44]. The molecular structure of these proteins was entirely described using the cyanogens cleavage method. The fragments obtained were analyzed and the results showed the abundance of tyrosine, lysine and particularly glutamic acid, in case of both proteins $[46,47]$. 

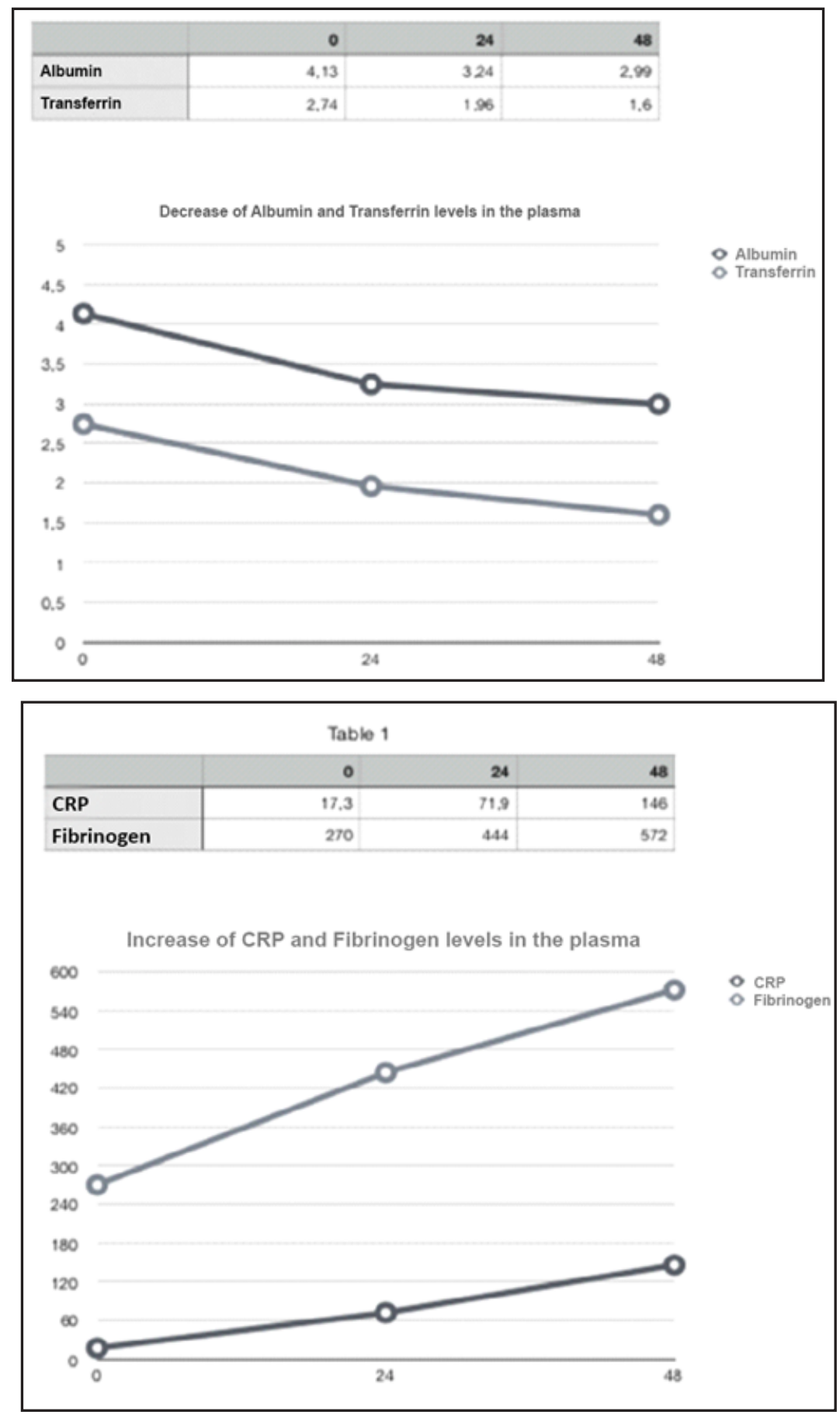

\begin{tabular}{|c|c|c|c|c|c|}
\hline \multicolumn{6}{|l|}{ Correlation Matrix } \\
\hline & & ALBUMIN & FIB & CRP & TRANSFERRIN \\
\hline \multirow[t]{2}{*}{ ALBUMIN } & Pearson's r & - & & & \\
\hline & p-value & - & & & \\
\hline \multirow[t]{2}{*}{ FIB } & Pearson's r & 0.056 & - & & \\
\hline & p-value & 0.667 & - & & \\
\hline \multirow[t]{2}{*}{ CRP } & Pearson's r & -0.009 & -0.074 & - & \\
\hline & p-value & 0.948 & 0.568 & - & \\
\hline \multirow[t]{2}{*}{ TRANSFERRIN } & Pearson's r & -0.010 & -0.051 & -0.012 & - \\
\hline & p-value & 0.936 & 0.696 & 0.924 & - \\
\hline
\end{tabular}

CRP has a molecular mass of $115 \mathrm{kda}$ and 1200 amino acids in its structure while fibrinogen (being one of the largest hepatic protein) has a mass of $340 \mathrm{kda}$ and 2400 amino acids in its structure [33-37].

If we consider the same amino acid substrate needed for protein synthesis [35], we can explain the same trend change in case of negative acute phase proteins and the differences found in case of positive acute phase proteins

\section{Graph 1}

Changes of plasma values of transferrin and albumin test results at 24 hours and 48 hours

\section{Graph 2}

Changes of plasma values of CRP and fibrinogen test results at 24 hours and 48 hours
Table 8

CORRELATIONS BETWEEN THE VALUES OF ALBUMIN, TRANSFERRIN, CRP AND FIBRINOGEN TEST RESULTS BEFORE THE MAIOR SURGERY 


\begin{tabular}{|c|c|c|c|c|c|}
\hline \multicolumn{6}{|l|}{ Correlation Matrix } \\
\hline & & ALB / 24 & FIB / 24 & CRP / 24 & TRANSFERRIN / 24 \\
\hline \multirow[t]{2}{*}{ ALB / 24} & Pearson's r & - & & & \\
\hline & p-value & - & & & \\
\hline \multirow[t]{2}{*}{$\mathrm{FIB} / 24$} & Pearson's r & 0.364 & - & & \\
\hline & p-value & 0.004 & - & & \\
\hline \multirow[t]{2}{*}{ CRP / 24} & Pearson's r & -0.108 & 0.032 & - & \\
\hline & p-value & 0.403 & 0.807 & - & \\
\hline \multirow[t]{2}{*}{ TRANSFERRIN / 24} & Pearson's r & 0.162 & 0.280 & -0.225 & - \\
\hline & $\mathrm{p}$-value & 0.208 & 0.028 & 0.079 & - \\
\hline & & ALB / 48 & $\mathrm{FIB} / 48$ & CRP /48 & TRANSFERRIN $/ 48$ \\
\hline \multirow[t]{2}{*}{ ALB $/ 48$} & Pearson's r & - & & & \\
\hline & p-value & - & & & \\
\hline \multirow[t]{2}{*}{$\mathrm{FIB} / 48$} & Pearson's r & -0.017 & - & & \\
\hline & p-value & 0.899 & - & & \\
\hline \multirow[t]{2}{*}{ CRP /48 } & Pearson's r & -0.203 & 0.298 & - & \\
\hline & p-value & 0.113 & 0.019 & - & \\
\hline \multirow[t]{2}{*}{ TRANSFERRIN /48 } & Pearson's r & -0.046 & 0.199 & -0.105 & - \\
\hline & $\mathrm{p}$-value & 0.724 & 0.121 & 0.416 & - \\
\hline
\end{tabular}

Table 9

CORRELATIONS BETWEEN THE VALUES OF ALBUMIN, TRANSFERRIN, CRP AND FIBRINOGEN TEST RESULTS 24 hours AFTER THE MAJOR SURGERY
Table 10

CORRELATIONS BETWEEN THE VALUES OF ALBUMIN, TRANSFERRIN, CRP AND FIBRINOGEN TEST RESULTS 48 hours AFTER THE MAI OR SURGERY

\begin{tabular}{|llcc|}
\hline Correlation Matrix & & \\
\hline & & ALBUMIN & TP \\
\hline ALBUMIN & Pearson's r & - & \\
& p-value & - & \\
TP & Pearson's r & 0.633 & - \\
& p-value & $<.001$ & - \\
\hline
\end{tabular}

\begin{tabular}{|lrrrrr|}
\hline & Sum of Squares & df & Mean Square & F & p \\
\hline Albumin & 33.35 & 2 & 16.6733 & 414 & $<.001$ \\
Residual & 4.91 & 122 & 0.0402 & & \\
Transferrin & 31.19 & 2 & 15.5953 & 641 & $<.001$ \\
Residual & 2.97 & 122 & 0.0243 & & \\
Albumin * Transferrin & $1.93 \mathrm{e}-28$ & 4 & $4.82 \mathrm{e}-29$ & $1.59 \mathrm{e}-10$ & 1.000 \\
Residual & $7.40 \mathrm{e}-17$ & 244 & $3.03 \mathrm{e}-19$ & & \\
\hline
\end{tabular}

Table 11

CORRELATIONS BETWEEN ALBUMIN AND TOTAL PROTEIN TEST RESULTS

\begin{tabular}{|lrrrrr|}
\hline Within Subjects Effects & \multicolumn{7}{l|}{} & & & \\
\hline & Sum of Squares & df & Mean Square & F & p \\
\hline CRP & 391376 & 2 & 195688 & 219 & $<.001$ \\
Residual & 108845 & 122 & 892 & & \\
FIBRINOGEN & $2.13 e+6$ & 2 & $1.07 e+6$ & 225 & $<.001$ \\
Residual & 578554 & 122 & 4742 & & \\
CRP * FIBRINOGEN & $2.67 e-25$ & 4 & $6.68 \mathrm{e}-26$ & $-1.40 \mathrm{e}-13$ & 1.000 \\
Residual & $-1.16 \mathrm{e}-10$ & 244 & $-4.77 \mathrm{e}-13$ & & \\
\hline Note. Type 3 Sums of Squares & & & & \\
\hline
\end{tabular}

Table 12

MULTIPLE ANOVA TEST COMPARING ALL THE VALUES OF ALBUMIN AND TRANSFERRIN AT THE THREE DIFFERENT TIME INTERVALS (BEFORE THE MAJOR SURGERY, 24 AND 48 hours AFTER THE INTERVENTION)

Table 13

MULTIPLE ANOVA TEST COMPARING ALL THE VALUES OF CRP AND FIBRINOGEN AT THE THREE DIFFERENT TIME INTERVALS (BEFORE THE MAIOR SURGERY, 24 AND 48 hours AFTER THE INTERVENTION)
Correlation tests do not show any interaction between these four proteins at all three moments of determination. The only validated correlation $(p<0.001)$ is between albumin and total protein [38]. This strong correlation is explained by the fact that the albumin concentration determines around $60 \%$ of total protein concentration.

The statistical tests show that there are no interactions between the values of transferrin and albumin on one hand and fibrinogen and CRP on the other. Furthermore, we conducted the multiple ANOVA correlation test which showed no interaction between albumin, transferrin, fibrinogen and CRP in the plasma at all three moments of determination.
A major limitation of this study is that the interleukins were not determined (ILI and IL6). As a result, we are not able to clearly evaluate the relation between these interleukins and acute phase proteins. Further studies should be performed to investigate this aspect as well. So far, it has been demonstrated that it is very hard to highlight a correlation between the values of interleukins and the values of these plasma proteins [52].

There should also be mentioned that in case of systemic inflammation, acute phase proteins are synthetized also in the vascular endothelium and macrophages besides the liver. This secondary synthesis does not seem to contribute significantly to either the normal values in the plasma or to 
increase the concentration in case of the acute phase response [45].

\section{Conclusions}

From this study, it can be concluded that positive acute phase proteins have different trend changes when compared to negative acute phase proteins. So far, the main explanation accepted by the majority of authors is the common amino acid substrate needed for protein synthesis. This substrate is very limited due to protein catabolism which occurs in the setting of systemic inflammation. According to this study, the protein synthesis depends on the molecular mass of each protein and even the types of amino acids found in their structure.

In conclusion, protein synthesis in the acute phase response is a highly complex mechanism which involves multiple factors and this study has demonstrated that these processes are independent of each other and further research is needed to clearly understand the phenomenon.

\section{References}

1. NICOLESCU,C., POP,A., MIHU,A., PILAT,L., BEDREAG,O., NICOLESCU,L. The evaluation of the role of cytokines TNF- Alpha and IL6 in the production of hypoalbuminemia in patients undergoing major surgical intervention. Rev. Chim.,(Bucharest),69, no.7,2018, p.1830

2. GABAY,C., KUSHNER,I. Acute phase proteins and other systemic responses to inflammation. N Engl J Med 1999; 340: 448-54.

3. BAUMANN,H., GAULDIE,J. The acute phase response. Immunol Today $1994 ; 15: 74-80$.

4. KRAVITZ,M., PITASHNNY,M., SHOENFELD,Y. Protective moleculesCreactive protein (CRP), serum amyloid p(SAP) pentraxin 3 (PTX3), manose-binding lectin (MBL) and apolipoprotein al (Apo A1) and their autoantibodies; prevalence and clinical significance in autoimmunity. J Cli Immuno 2005; 25: 582-591.

5. MIZGERD,JP., SPIEKER,MR., DOERSCHUK,CM. Early response cytokines and innate immunity: essantil roles for TNF alfa and type I IL1 receptor during Escherichia Colli pneumonia in mice. J Immunol 2001; 1666: 4042-4048.

6. OLDENBURG,HAS., PRUITT,JH., LAZARUS,DD., et al. Interleukin 1 binding to itstype I, but not type II, receptor modulates the in vivo acute phase response. Cytokine 1995; 7: 510-516.

7. ZHENG,H., FLETCHER,W., KOZAK,M., JIANG,J ., HOFMMAN,CA., CONN,D., SOSYZYNSKI,C., GRABIEC,ME., TRUMBAUER,A., SHAW,EA. Resistance to fever infection and impaired acute-phase response in interleukin-1-deficit in mice. Immunity 1995; 39-19.

8. THORN,CF., LU,ZY., WHITEHEAD,AS. Regulation of the human acute phase serum amyloid A genes by tumor necrosis factor -alfa, interleukin-6 and glucocorticoides in hepatic and epithelial cell lines. Scand I Immunol 2004;59(2):152-8.

9. MOSHAGE,H. Cytokines and the hepatic acute phase response. J ournal of Pathology 1995;181:257-266

10. KISHIMOTO,T., AKIRA,S., NARAZAKI,M., TAGA,T. Interleukin-6 family ofcytokines and gp130. Blood 1995; 86: 1243-1254.

11. JONES,MR., QUINTON,LJ ., SIMMS,BT., LUPA,MT., KOGAN,MS., MIZGERD,J P. Roles of interleukin-6 in activation of STAT proteins and recruitment of neutrophils during E. Colli pneumonia. J Infect Dis 2006;193(3): 360-369.

12. Henrich,PC., BEHRMANN,I., HAAN,S., HERMANNS,H., MULLER NEWEN,G., SCHAPER,F. Principles of interleukin (IL)-6-type cytokine signaling and its regulation. Biochem J 2003; 374:1-20.

13. BELLIDO,T., STAHL,N., FARRUGGELLA,TJ., BORBA,V., YANCOPOULOS,GD., MANOLAGAS,SC. Detection of receptors for IL6, IL-11, LIF, oncostatin M and CNTF in bone marrow stromal/ osteoblastic cells. J Clin Invest 1996; 97: 431-437.

14. KOPF,M., BAUMMAN,H., FREER,G., FREUDENBERG,M., LAMERS,M., KISHIMOTO,T., ZINKERNAGEL,R., BLUETHMANN,H., KOHLER,G. Impaired immune and acute -phase responses in interleukin-6deficient mice. Nature 1994; 368(6469):339-42. 3952

http://www.revistadechimie.ro
15.BETTS, ., CHESHIRE,J K., AKIRA,S., KISHIMOTO,T., W OO,P. The role of NF-kappa B and NF-IL6 transactivating factors in the synergistic activation of human serum amyloid $A$ gene expression by interleukin1 and interleukin-6. J Biol Chem 1993; 268(34): 25624-31.

16. KISHIMOTO,T., TAGA,T., AKIRA,S. Cytokine signal transduction. Cell 1994; 76:253-262.

17. WEGENKA,UM., BUSCHMANN, ., LUTTICKEN,C., HEINRICH,PC., HORN,F. Acute phase response factor, a nuclear factor binding to acute-phase responseelements, is rapidly activated by IL- 6 at the posttranslational level. Mol Cell Biol 1993; 13: 276-288.

18. IHLE,J N. STATs: signal transducers and activators of transcription. Cell 1996; 84: 331-334.

19. ALONZI,TD., MARITANO,B., GORGONI,G., RIZZUTO,C., POLI,V. Essential role of STAT3 in the control of acute - phase as revealed by inducible gene inactivation in the liver. Mol Cell Biol 2001; 21:16211632.

20. NESBITT,JE., FUENTES,NL., FULLER,GM. Ciliary neurotrophic factor regulates fibrinogen gene expression in hepatocytes by binding to the interleukin-6 receptor. Biochem Biophys Res Commun 1993; 190: 544-550.

21. KOPF,M., BAUMANN,H., FREER,G., et al. Impaired immune and acute-phaseresponses in IL-6-deficient mice. Nature 1994; 368: 339342.

22. FATTORI,E., CAPPELLETTI,M., COSTA,P., et al. Defective inflammatory response inlL-6-deficient mice. J Exp Med 1994; 180: 1243-1250.

23. AREND,W P. Interleukin-1 receptor antagonist. J Clin Invest 1991; 88:1445-1451.

24. LI,Q., VERMA,IM. NF-kb regulation in the immune system. Nat Rev Immunol 2002; 2:725-734.

25.DRIPPS, DJ .,VERDERBER, E., NG,RK.,THOMPSON,RC., EISENBERG,SP., Interleukin-1 receptor antagonist binds to the type II interleukin-1 receptoron B cells and neutrophils. J Biol Chem 1991; 266: 20311-20315.

26. MC INTYRE,KW., STEPAN,G] ., KOLINSKY,KD., et al. Inhibition of interleukin 1(IL-1) binding and bioactivity in vitro and modulation of acute inflammation in vivo by IL-1 receptor antagonist and anti-IL-1 receptor monoclonalantibody. J Exp Med 1991; 173: 931-939.

27. GERSHENWALD,J E., FONG,Y., FAHEY,TJ ., et al. Interleukin 1 receptor blockadeattenuates the host inflammatory response. Proc Natl Acad Sci USA 1990; 87: 4966-4970.

28. BEVAN,S., RAYNES,J G. IL-1 receptor antagonist regulation of acute phaseprotein synthesis in human hepatoma cells. J Immunol 1991; 147: 2574-2578.

29. GABAY,C., GENIN,B., MENTHA,G., IYNEDJIAN,PB., ROUXLOMBARD,P., GUERNEP,A. IL-1 receptor antagonist (IL-1Ra) does not inhibit the production of $C$-reactive protein or serum amyloid $A$ protein by human primary hepatocytes. Differential regulation in normal and tumour cells. Clin Exp Immunol 1995; 100: 306-313.

30. CONTI,P., BARTLE,L., BARBACANE,RC., REALE,M., SIPE,J D. The down-regulation of IL-6 stimulated fibrinogen steady state $\mathrm{MRNA}$ and protein levels by human recombinant IL-1 is not PGE2-dependent: effects of IL-1 receptorantagonist (IL-1RA). Mol Cell Biochem 1995; 142: 171-178.

31.GIRI,J G., WELLS,J ., DOWER,SK., et al. Elevated levels of shed type II IL-1receptor in sepsis. J Immunol 1994; 153: 5802-5809.

32. PRUITT,J H., WELBORN,MB., EDWARDS,PD., et al. Increased soluble IL-1 type IIreceptor concentrations in postoperative patients and in patients with sepsis syndrome. Blood 1996; 87: 3282-3288.

33. MOSHAGE,H., YAP,SH. Molecular and cellular biology of the liver. Curr Opinion Gastroenterol 1993; 9: 367-373.

34. FALCO,A., CARTWRIGHT,JR., WIEGERTJES,GF., HOOLE,D. Molecular characterization and expression analysis of two new Creactive protein genes from common carp (Cyprus carpio). Dev Comp Immunol 2012 37:127-138.

35. MARQUES,AT., NORDIO,I., LECCHI,C., GRILLI,G., GIUDICE,C., CECILIANI,F. Widespred extrahepatic expression of acute-phase proteins in healthy chicken tissues. Vet Immunol Immunopathol 2017; 190:10-17. 
36. BERTELESEN,MF., KJEIGAARD-HANSEN,M., GRONHALD,C., HEEGAARD,PM., JACOBSEN,S. Identification of acute phase proteins and assays applicable in nondomesticated mammals. J Zoo Wild Med 2009; 40:199-203.

37.MC NURLAN,MA., SANDGREN,A., HUNTER,K., ESSEN,P., GARLICK,PJ ., WERNERMAN,J. Protein synthesis rates in skeletal muscle, lymphocytes and albumin with stress hormone infusion in healthy man. Metabolism 1996; 45(11); 1388-1394

38.FUHRMAN,MP., CHARNEY,P., MUELLER,CM. Hepatic proteins and nutrition assessment. J Am Diet Assoc 2004; 104(8):1258-1264.

39.NICHOLSON,J P., WOLMARARANS,MR., PARK,GR. The role of albumin in critical illness. Br J Anaesth 2000; 85(4); 599-610.

40. JIN,S., GAUTAM,V., Naseem,S. Acute-phase proteins: As diagnostic tool. J Pharm Bioallied Sci. 2011;3(1):118-127.

41. SALAZAR, ., MARTÍNEZ,MS., CHÁVEZ-CASTILLO,M., NUNEZ,V., ANEZ,R., TORRES,Y., TOLEDO,A., CHACÍN,M., SILVA,C., PACHECO,E., ROJAS, ., BERMÚDEZ,V. C-Reactive Protein: An In-Depth Look into Structure, Function, and Regulation. Res Notices 2014; 2014:653045. 42. TENNENT,GA., BRENNAN,SO., STANGOU,AJ ., O'GRADY, ., HAWKINS,PN., PEPYS,MB. Human plasma fibrinogen is synthesized in the liver. Blood 2007;109(5):1971-4.

43. CARACENI,P., TUFONI,M., BONAVITA,ME. Clinical use of albumin. Blood Transfus 2013;11 Suppl 4(Suppl 4):s18-s25.

44. MACGILLIVRAY,RT., MENDEZ,E., SINHA,SK., SUTTON,MR. LINEBACK-ZINS,]., BREW,K. The complete amino acid sequence of human serum transferrin. Proc Natl Acad Sci U S A. 1982; 79(8):25042508.
45. SANDER,LE., SACKETT,SD., DIERSSEN,U., et al. Hepatic acute-phase proteins control innate immune responses during infection by promoting myeloid-derived suppressor cell function. J Exp Med 2010;207(7):1453-1464.

46.ZINGDE,SM., SHIRSAT,NV., GOTHOSKAR,BP. Peptide Mapping of Proteins in Gel Bands after Partial Cleavage with Acidic Cyanogen Bromide Vapors. Analytical Biochemistry 1986; 155(1): 10-3.

47.Mc MENAMY,RH., DINTZIS,HM., WATSON,F. Cyanogen Bromide Fragments of Human Serum Albumin. The Journal of Biological Chemistry 1971; 246: 4744-4750.

48.GRUYS,E., TOUSSAINT,MJ ., NIEW OLD,TA., KOOPMANS,SJ . Acute phase reaction and acute phase proteins. J Zhejiang Univ Sci B. 2005;6(11):1045-1056. doi:10.1631/jzus.2005.B1045

49. GULHAR,R., JIALAL,I. Physiology, Acute Phase Reactants. [Updated 2019 Jan 20]. In: StatPearls [Internet]. Treasure Island (FL): StatPearls Publishing; 2019 Jan.

50. CECILIANI,F., GIORDANO,A., SPAGNOLO,V. The systemic reaction during inflammation: the acute-phase proteins. Protein Pept Lett. 2002 Jun;9(3):211-23.

51. CRAY,C., ZAIAS, ., ALTMAN,NH. Acute phase response in animals: a review. Comp Med. 2009;59(6):517-526.

52. PAWLACZYK,M., SOBIESKA,M. A correlation between acute phase proteins and cytokines in patients suffering from mycosis fungoides. Acta Dermatovenerol Alp Pannonica Adriat. 2006 Sep;15(3):107-12.

Manuscript received: 27.06 .2019 